\title{
Antibiogram Study of Bacterial Pathogen from Tilapia Fish in Bangladesh
}

\author{
Sume Begum ${ }^{1, a}$, Md. Salauddin ${ }^{1, b}$, Md. Khaled Hossain ${ }^{1, c}$, Mst. Deloara Begum ${ }^{1, d, *}$ \\ Department of Microbiology, Faculty of Veterinary and Animal Science, Hajee Mohammad Danesh Science and Technology University,
} Dinajpur-5200, Bangladesh., *Corresponding author

\begin{tabular}{l|l}
\hline A R T I C L E I N F O & A B S T R A C T \\
\hline Research Article & $\begin{array}{l}\text { Bacterial pathogens are isolated, identified and antibiogram were performed by taking the skin, } \\
\text { gills and intestine of twenty randomly selected Tilapia fish (Oreochromis niloticus) that collected } \\
\text { from local market of the Dinajpur city, Bangladesh. A serial dilution was prepared with the stated } \\
\text { sample and at the amount of 0.1 ml was plated on nutrient agar, differential also specific media } \\
\text { respectively. Then gram's staining, colony morphology, biochemical test and antibiogram } \\
\text { performed respectively. The four different isolated species with frequency of occurrence are } \\
31(40.26 \%) \text { Escherichia coli, 3 (29.87\%) Staphylococcus spp., 13 (16.88\%) Pseudomonas spp., } \\
10(12.99 \%) \text { Salmonella spp. respectively. Some of these pathogens have tendency to transmit to } \\
\text { man, who eat fish or deal with fish and fish products. Amoxicillin, Cefixime, Azithromycin, } \\
\text { Accepted : 03/12/2018 } \\
\text { Chloramphenicol, Ciprofloxacin, Penicillin G, Erythromycin, Vancomycin, Gentamicin and } \\
\text { Neomycin antibiotics was performed during sensitivity test. Among the total (77) isolated bacteria } \\
\text { were sensitive to gentamycin, chloramphenicol, ciprofloxacin and Azithromycin but resistant to } \\
\text { Amoxicillin, Penicillin G, Vancomycin and Erythromycin. The study was conducted in term of } \\
\text { medical importance. Hence it is considered that a variety of bacterial species can be associated } \\
\text { with fresh Tilapia fish related pathogen to humans. }\end{array}$ \\
$\begin{array}{l}\text { Fish sample } \\
\text { Antibiogram, } \\
\begin{array}{l}\text { Oreochromis niloticus } \\
\text { Public health awareness }\end{array}\end{array}$
\end{tabular}

Public health awarenes

\begin{tabular}{|c|c|c|}
\hline $\begin{array}{l}\text { sume30dvm@gmail.com } \\
\text { khossainhstu@gmail.com }\end{array}$ & $\begin{array}{l}\text { (i) https://orcid.org/0000-0002-8001-5346 } \mathrm{b} @ \text { salauddin.dvm@gmail.com } \\
\text { (i) https://orcid.org/0000-0002-0138-4523 } \mathrm{d} @ \text { deloara_dvm@yahoo.com }\end{array}$ & $\begin{array}{l}\text { (iD https://orcid.org/0000-0002-8990-3868 } \\
\text { (iD https://orcid.org/0000-0001-9447-2516 }\end{array}$ \\
\hline
\end{tabular}

(9) () (9) This work is licensed under Creative Commons Attribution 4.0 International License

\section{Introduction}

Fish has been one of the main source of foods for humans and still constitute an important part of the diet in many countries (Leisner et al., 2001). The shortage of human dietary protein can be provided by fish protein, particularly in developing countries, where the protein shortage is serious. The advantage of fish is its easy digestibility and high nutritional value. Resulting, there is a considerable increase in the demand for fish being the cheapest source of animal protein (Ladipo et al., 1981). An estimated 1 billion people rely on fish as their main source of animal protein (FAO, 2007). Fish contributes about $60 \%$ of the world supply of protein, and $60 \%$ of the developing world derives more than $30 \%$ of their animal protein from fish (Emikpe et al., 2011). Fishes are generally regarded as safe, nutritious and beneficial but aquaculture products have sometimes been associated with certain food safety issues (WHO, 2007).

Fish play an important role in the Bangladeshi diet, contributing $60 \%$ of national animal protein consumption, representing a crucial source of micro-nutrients (Belton et al., 2011). The total annual fish production in Bangladesh was estimated at 3.06 million tons in 2010-2011 fiscal year, of which 1.46 million tons (48\%) were obtained from inland aquaculture, 1.05 million tons (34\%) from inland capture fisheries and 0.55 million tons (18\%) from marine fisheries. The total annual fish production has gradually increased from 1.78 million tons in 2000-01 to 3.06 million tons in 2010-11, an average annual growth rate of $7 \%$ during the last decade (FRSS, 2012).

Tilapia is a tropical fish belonging to the family Cichlidae, genus tilapia native to Africa (Shirak et al., 2009). Due to its rapid growth and palatability, this species has been widely introduced in countries with a tropical climate around the world and has become globally important aquatic species produced in nearly 100 countries worldwide (Romana et al., 2004). Tilapia and fish in general can be contaminated with pathogenic microorganisms because of the texture of their flesh, their living habits and also from the microbe laden habitat they inhabit. Isolation and identification of microbial food contaminants help to understand how infectious agents enter and spread through the food chain and therefore come up with procedures to prevent or minimize exposure of the consumer to such agents. Bacteria can enter the fish body through the gills or skin or it can stay on the surface of the body (Douglas, 2007). Fishes skin surface, intestine and gills, however, carries high microbial load (Mhango et al., 2010). 
Some of these pathogens could transmit to man who eat fish meat or deal with fish and fish products (Goncalves et al., 1992; Weinstein et al., 1997; Zlotkin et al., 2003). Aeromonas sp. and Pseudomonas spp. isolated from $O$. niloticus by $35.96 \%$ and $16.88 \%$ respectively (Abou ElAtta, 2003). Pseudomonas was widely distributed in ecosystem and was recognized as one of the primary cause of bacterial hemorrhagic septicemia in fish, pseudomonas septicemia, usually is associated with environmentally stressful conditions such as overcrowding, low temperature, injuries (Aly, 1994; Allen et al., 1983). It may be a secondary invader of damaged fish tissue (Roberts and Home, 1978). P. fluorescens considered the causative agent of red spot disease attack all kinds of cultured fishes where the disease raised in running water ponds, stagnant water ponds as well as in cages (Angka and Lioe, 1982), the disease favored by stressor as low temperature, injuries and recorded that the incidence of pseudomonas septicemia was $11 \%$ (Eissa et al., 1996).

Current knowledge of the health and environmental impact of antibiotics used in aquaculture is poor particularly in developing countries. Drug residues may remain in fish used for human consumption and consequently the antibiotics released into the environment can lead to the development of antibiotic resistant bacteria in the food chain (Cabello, 2006).

By monitoring the bacteria contents of fish organs, the quality of fish can be measured since these will affect the storage life and quality of the fishery products (Kaneko, 1971). In order to provide a predictive capability for possible disease outbreaks and provide an opportunity to design preventive management actions, detailed information of the bacterial load and types of bacteria associated with the organs of apparently healthy Tilapia fish is needed.

The present study aimed to isolate and identify bacterial pathogens in locally available Tilapia fish species, to demonstrate the drug-resistance traits of the isolates with a view to provide potential approaches for improving the quality assurance and create awareness among the consumers. Therefore, the study was designed i) To isolate and identify the bacterial pathogens from Tilapia fish samples collected from local fish market of Dinajpur city and ii) To detect the antibiotic sensitivity pattern of identified isolates.

\section{Materials and Methods}

\section{Collection of Fish Samples}

A total number of 60 samples [gill (20), skin (20) and intestine (20)] of Tilapia (Oreochromis niloticus) fishes of different sizes $200 \mathrm{~g}, 300 \mathrm{~g}$ and length $17 \mathrm{~cm}, 23 \mathrm{~cm}$ were collected aseptically for the isolation and identification of bacteria.

Gills: One to $2 \mathrm{~cm}^{2}$ pieces of gills from Tilapia (Oreochromis niloticus) fishes were cut with sterile scissor and taken by sterile forceps for inoculation onto appropriate culture medium.

Intestines: One to $2 \mathrm{~cm}$ proximal segments of intestines from Tilapia (Oreochromis niloticus) fishes were cut with sterile scissor and taken by sterile forceps for inoculation onto appropriate culture medium.
Skin: Skin sample collected from Tilapia (Oreochromis niloticus) fishes with the help of cotton swab for inoculation onto appropriate culture medium.

\section{Preparation of Culture Media}

The entire study is divided into two steps. The first step includes the isolation of bacteria from the collected Tilapia fish samples. The identification was made according to their cultural, staining morphological biochemical properties. The second step is study of antibacterial sensitivity pattern of the isolated bacteria.

\section{Sample Collection and Sample Processing}

Tilapia fish samples (60) from local fish market of Dinajpur city (Bahadur bazaar, Railgate bazaar and Gopalgong bazaar) were collected aseptically and brought to the bacteriology laboratory, Department of Microbiology, HSTU, Dinajpur with necessary precautions for bacteriological examination. At first, Samples were rinsed thoroughly with sterile distilled water. Then tilapia fish (gill, skin and intestine) samples were homogenized through blending with $90 \mathrm{ml}$ peptone water (Cappuccino and Sherman, 1996). Then 1-10 fold dilutions were performed.

\section{Serial Dilution of Sample}

Serial 10 fold dilutions of each of the samples in a series of dilution tubes were prepared. At first for each of the processed samples 10 sterile test tubes were placed on a test tube holder rack containing $9 \mathrm{ml}$ of $2 \%$ buffered peptone water. $1 \mathrm{ml}$ processed sample was mixed with 9 $\mathrm{ml}$ of Phosphate buffer solution in the $1^{\text {st }}$ test tube in order to make $10^{-1}$ dilution. Then $1 \mathrm{ml}$ solution from $1^{\text {st }}$ test tube mixed with $2^{\text {nd }}$ test tube, then from $2^{\text {nd }}$ test tube to $3^{\text {rd }}$ test tube and finally $9^{\text {th }}$ to $10^{\text {th }}$ test tube and $1 \mathrm{ml}$ discard from $10^{\text {th }}$ test tube by the help of pipette and in every steps mixing was done properly.

\section{Isolation and Identification of Bacteria}

Processed samples are primarily cultured in both nutrient agar and nutrient broth at $37^{\circ} \mathrm{C}$ for 24 hours. Simultaneously bacteria inoculated as Sub-culture on Eosin Methyl Blue agar (EMB), Salmonella Shigella agar (SS), Mannitol salt agar (MSA) and Cetrimide agar media at $37^{\circ} \mathrm{C}$ for 24 hours. Microscopically observed bacterial morphology after 24 hours of every sub-culture. Biochemical characterization of isolates by using Indole, Citrate utilization test, TSI, MR-VP and MIU. Incubate at $37^{\circ} \mathrm{C}$ for 24,48 and 72 hours. After that, spreading of pure bacterial culture colony onto Mueller Hinton agar at $37^{\circ} \mathrm{C}$ for 24 hours and placed on it antibiotic disc to determine the sensitivity and susceptibility of isolates against the antibiotic disc by Disc-diffusion method.

\section{Antibiotic Susceptibility Test}

Susceptibility of isolates of Escherichia coli, salmonella spp., Staphylococcus spp. and Pseudomonas spp. To different antimicrobial agents was performed to determine the drug sensitivity pattern and to interpret their disease potential. This method allows for the rapid determination of the efficacy of a drug by measuring the diameter of the zone of inhibition that results from diffusion of the agent into the medium through the disc. 
The overnight nutrient broth cultured organism spread uniformly with the help of sterile glass spreader. Antibacterial disc was applied aseptically to the surface of the plate at an appropriate arrangement with the help of sterile forceps and incubated at hours, aerobically (Carter, 1979). Antibiotic sensitivity pattern of isolated Escherichia coli, Salmonella spp., Staphylococcus spp. and Pseudomonas spp. were performed against 10 commonly used antibiotics belonging to different groups. After incubation, diameters of the zones of inhibition for individual antibacterial agents were designated as sensitive, intermediate and resistant.

The sensitivity of isolates to antibiotics was determined by disc diffusion technique. The isolates were cultured into peptone water and incubated at $37^{\circ} \mathrm{C}$ for two hours. A Petri dish containing Muller Hinton Agar (MHA) medium, was put in the incubators for 30 minutes to dry and then inoculated with $2 \mathrm{ml}$ volume of the test culture. The inoculated culture was evenly distributed by rotation, the excess inoculums was withdrawn by sterile Pasteur pipette and the plate was left to dry at room temperature for 15 minutes. To determine the drug sensitivity pattern of different isolated bacteria different types of commercially available antibiotic discs (Oxoid Ltd., UK) were placed on the surface of the inoculated medium with a sterile forceps and pressed gently to ensure good contact with the surface of the medium. The plates were then incubated at $37^{\circ} \mathrm{C}$. GEN $=$ Gentamicin $(10 \mu \mathrm{g} /$ disc $), \mathrm{AMX}=$ Amoxicillin $(30$ $\mu \mathrm{g} /$ disc $), \quad \mathrm{C}=$ Chloramphenicol $(30 \mu \mathrm{g} / \mathrm{disc}), \mathrm{CIP}=$ Ciprofloxacin $(5 \mu \mathrm{g} /$ disc $), \mathrm{CFM}=$ Cefixime $(5 \mu \mathrm{g} / \mathrm{disc})$, $\mathrm{AZM}=$ Azithromycin $(30 \mu \mathrm{g} /$ disc $), \mathrm{E}=$ Erythromycin $(15$ $\mu \mathrm{g} /$ disc $), \mathrm{P}=$ Penicillin $\mathrm{G}(10 \mu \mathrm{g} /$ disc $), \mathrm{N}=$ Neomycin $(30$ $\mu \mathrm{g} / \mathrm{disc}), \quad \mathrm{VA}=$ Vancomycin $(30 \mu \mathrm{g} / \mathrm{disc})$ are the antibiotics that were tested against the selected organism (Chonoko et al., 2014).

\section{Reading Plates and Interpreting Results}

After 24 hours of incubation, each plate was examined. If the plate was satisfactorily streaked, and the inoculum was correct, the resulting zones oh inhibition will be uniformly circular and there will be a confluent lawn of growth. If individual colonies were apparent, the inoculum was too light and the test must be repeated. The diameters of the zones of complete inhibition (as judged by the unaided eye) were measured, including the diameter of the disc. Zones were measured to the nearest whole millimeter, using sliding calipers or a ruler, which was held on the back of the inverted Petri plate. The Petri plate was held a few inches above a black, nonreflecting background and zones are measured in millimeter $(\mathrm{mm})$ from the upper surface of the agar illuminated with reflected light, with the cover removed (EUCAST, 2015).

\section{Results and Discussions}

\section{Isolation and Identification of Bacteria}

The 60 samples gave 77 isolates were both Gram negative bacteria and Gram positive bacteria. Among them 31 (40.26\%) Escherichia coli, 10(12.99\%) salmonella spp., 23 (29.87\%) Staphylococcus spp. and 13 (16.88\%) Pseudomonas spp. 22 isolates from 20 gill samples where $9(40.91 \%)$ Escherichia coli, 4(18.18\%) salmonella spp., 6(27.27\%) Staphylococcus spp. and 3(13.64\%) Pseudomonas spp. found. 26 bacteria were isolated from 20 intestine samples where 10 (38.46\%) Escherichia coli, $3(11.55 \%)$ salmonella spp., 9 (34.62\%) Staphylococcus spp., and $4(15.38 \%)$ Pseudomonas spp. and 29 isolates bacteria were 12 (41.38\%) Escherichia coli, 3 (10.34\%) salmonella spp., 8 (27.59\%) Staphylococcus spp. and 6 (20.69\%) Pseudomonas spp. obtained from 20 skin samples (Table 1).

\section{Results of Biochemical Tests}

The isolated organisms were confirmed by different biochemical tests. Result for E. coli, Salmonella spp., Staphylococcus spp. and Pseudomonas spp. are showed in Table 2.

\section{Results of Antibiotic Sensitivity Tests}

The results of antibiotics sensitivity tests of E. coli, Salmonella spp., Staphylococcus spp., and Pseudomonas spp. are presented in Table 3 and Figure 1 to Figure 8. The isolates were sensitive to gentamycin, azithromycin chloramphenicol and ciprofloxacin and resistance to amoxicillin, penicillin G. vancomycin and erythromycin. Highest zone of inhibition appears in Pseudomonas spp. (39 $\mathrm{mm})$ and intermediate zone appears in the case of $E$. coli $(15 \mathrm{~mm})$ and Staphylococcus spp. $(14 \mathrm{~mm})$.

Table 1 Frequency of occurrence of bacteria isolated from different samples of Tilapia fish

\begin{tabular}{l|ccccc}
\hline \multirow{2}{*}{ Samples } & \multirow{2}{*}{ TIBS } & \multicolumn{4}{c}{ No. of isolated bacteria } \\
\cline { 2 - 6 } & & Escherichia coli & Salmonella spp. & Staphylococcus spp. & Pseudomonas spp. \\
\hline Gills (20) & 22 & $9(40.91 \%)$ & $4(18.18 \%)$ & $6(27.27 \%)$ & $3(13.64 \%)$ \\
Intestine (20) & 26 & $10(38.46 \%)$ & $3(11.54 \%)$ & $9(34.62 \%)$ & $4(15.38 \%)$ \\
Skin (20) & 29 & $12(41.38 \%)$ & $3(10.34 \%)$ & $8(27.59 \%)$ & $6(20.69 \%)$ \\
\hline Total & 77 & 31 & 10 & 23 & 13 \\
\hline
\end{tabular}

TIBS: Total isolated bacteria from samples

Table 2 The results of Biochemical tests of E. coli, Salmonella spp., Staphylococcus spp., and Pseudomonas spp.

\begin{tabular}{|c|c|c|c|c|c|c|}
\hline Organisms & CUT & IT & TSI & MR & VP & MIU \\
\hline E. coli & - & + & $\mathrm{S}-\mathrm{A}, \mathrm{B}-\mathrm{A}, \mathrm{Gas}+, \mathrm{H}_{2} \mathrm{~S}-$ & + & - & + \\
\hline Salmonella spp. & 一 & - & $\mathrm{S}-\mathrm{Al}, \mathrm{B}-\mathrm{A}, \mathrm{Gas}+, \mathrm{H}_{2} \mathrm{~S}-$ & + & - & - \\
\hline Staphylococcus spp. & - & - & $\mathrm{S}-\mathrm{Al}, \mathrm{B}-\mathrm{A}, \mathrm{Gas}-, \mathrm{H}_{2} \mathrm{~S}-$ & + & + & - \\
\hline Pseudomonas spp. & + & - & $\mathrm{S}-\mathrm{A}, \mathrm{B}-\mathrm{A}, \mathrm{Gas}+, \mathrm{H}_{2} \mathrm{~S}-$ & - & - & + \\
\hline
\end{tabular}

(Legends: $\mathrm{S}=$ Slant, $\mathrm{B}=\mathrm{Butt}, \mathrm{A}=\mathrm{Acid}, \mathrm{Al}-$ Alkaline, $\mathrm{CUT}=$ Citrate utilization test, IT = Indole test, TSI = Triple sugar iron test, MR = Methyl-Red test, $\mathrm{VP}=$ Voges-Proskauer test, MIU = Motility indole urease, $+=$ Positive reaction, $-=$ Negative reaction). 
Table 3 Results of the antibiogram study

\begin{tabular}{|c|c|c|c|c|c|c|c|c|c|c|c|}
\hline \multirow[b]{2}{*}{ Isolates } & \multirow[b]{2}{*}{ DZI } & \multicolumn{10}{|c|}{ Antibacterial agents and Disc concentration ( $\mu \mathrm{g} /$ disk $)$} \\
\hline & & $\begin{array}{c}\text { GEN } \\
(10)\end{array}$ & $\begin{array}{c}\text { AMX } \\
(30)\end{array}$ & $\begin{array}{c}\mathrm{C} \\
(30)\end{array}$ & $\begin{array}{l}\text { CIP } \\
(5)\end{array}$ & $\begin{array}{c}\mathrm{CFM} \\
(5)\end{array}$ & $\begin{array}{c}\text { AZM } \\
(30)\end{array}$ & $\begin{array}{c}\mathrm{E} \\
(15)\end{array}$ & $\begin{array}{c}\mathrm{P} \\
(10)\end{array}$ & $\begin{array}{c}\mathrm{N} \\
(30)\end{array}$ & $\begin{array}{l}\mathrm{VA} \\
(30)\end{array}$ \\
\hline \multirow{3}{*}{ E.coli } & $\mathrm{S}$ & $19 \mathrm{~mm}$ & & $22 \mathrm{~mm}$ & & & $18 \mathrm{~mm}$ & & \multirow{3}{*}{\multicolumn{2}{|c|}{$15 \mathrm{~mm}$}} & \\
\hline & I & & & & & & & & & & \\
\hline & $\mathrm{R}$ & & 0 & & 0 & 0 & & 0 & & & 0 \\
\hline \multirow{3}{*}{ Salmonella spp. } & $\mathrm{S}$ & $23 \mathrm{~mm}$ & & & & $22 \mathrm{~mm}$ & $24 \mathrm{~mm}$ & & \multirow{3}{*}{\multicolumn{2}{|c|}{$18 \mathrm{~mm}$}} & \\
\hline & I & & & & $16 \mathrm{~mm}$ & & & & & & \\
\hline & $\mathrm{R}$ & & 0 & 0 & & & & 0 & & & 0 \\
\hline \multirow{3}{*}{ Staphylococcus spp. } & S & $21 \mathrm{~mm}$ & & $18 \mathrm{~mm}$ & $22 \mathrm{~mm}$ & $23 \mathrm{~mm}$ & $22 \mathrm{~mm}$ & \multirow{3}{*}{$18 \mathrm{~mm}$} & \multirow{3}{*}{\multicolumn{2}{|c|}{$14 \mathrm{~mm}$}} & \\
\hline & I & & & & & & & & & & \\
\hline & $\mathrm{R}$ & & 0 & & & & & & & & 0 \\
\hline \multirow{3}{*}{ Pseudomonas spp. } & $S$ & $19 \mathrm{~mm}$ & & & $39 \mathrm{~mm}$ & & $20 \mathrm{~mm}$ & & & & \\
\hline & I & & & & & & & & & & \\
\hline & $\mathrm{R}$ & & 0 & 0 & & 0 & & 0 & 0 & 0 & 0 \\
\hline
\end{tabular}

(Legends: DZI: Diameter of zone of inhibition(mm), S: Sensitive, I: Intermediate, R: Resistant, GEN = Gentamicin, AMX = Amoxicillin, $\mathrm{C}=$ Chloramphenicol, $\mathrm{CIP}=$ Ciprofloxacin, $\mathrm{CFM}=$ Cefixime, $\mathrm{AZM}=$ Azithromycin, $\mathrm{E}=$ Erythromycin, $\mathrm{P}=$ Penicillin $\mathrm{G}, \mathrm{N}=\mathrm{Neomycin}$, $\mathrm{VA}=$ Vancomycin, $0=$ No zone of inhibition.)

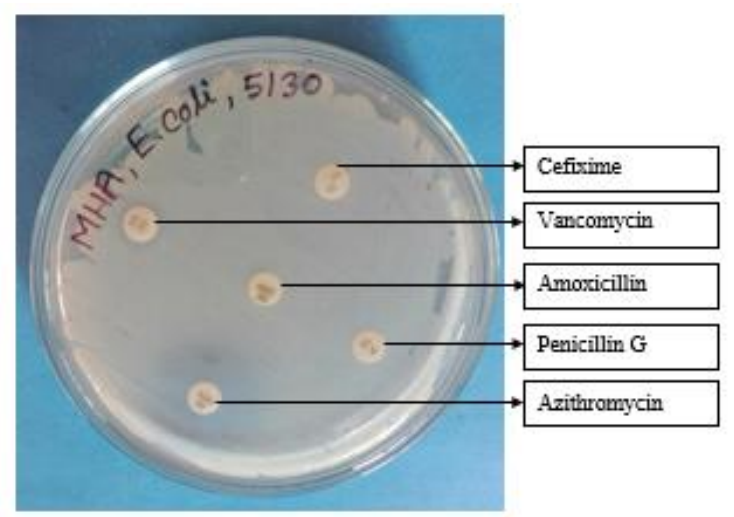

Figure 1 Antibiogram for E. coli (a)

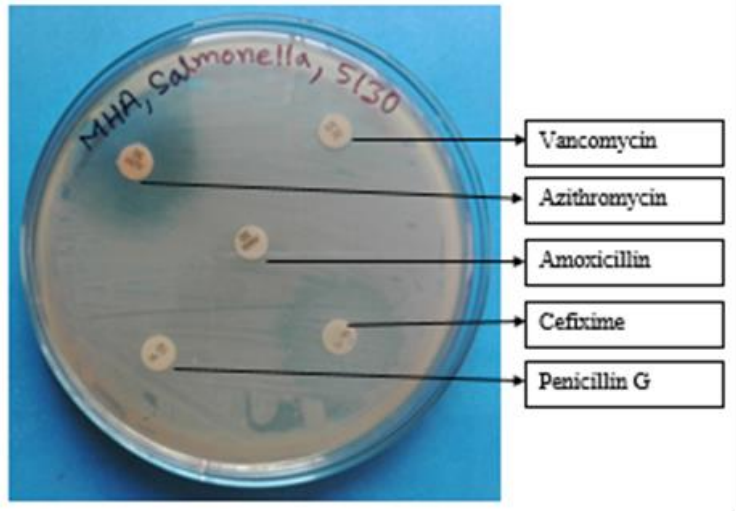

Figure 3 Antibiogram study of Salmonella spp. (a)

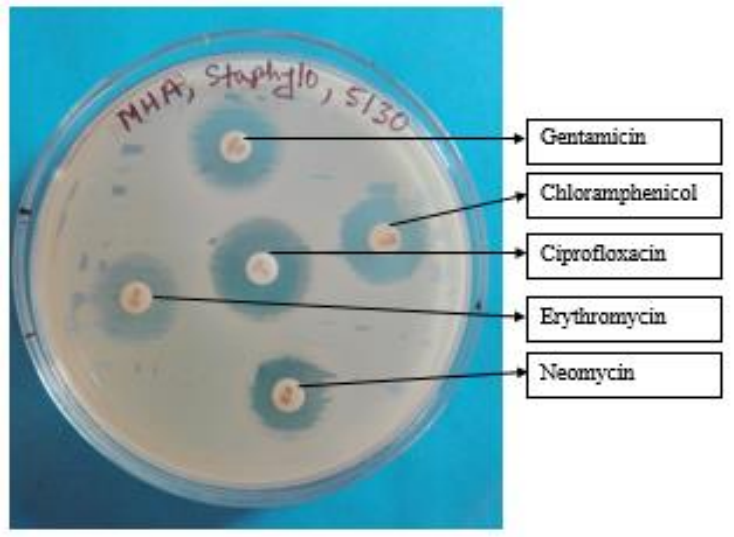

Figure 5 Antibiogram study of Staphylococcus spp. (a)

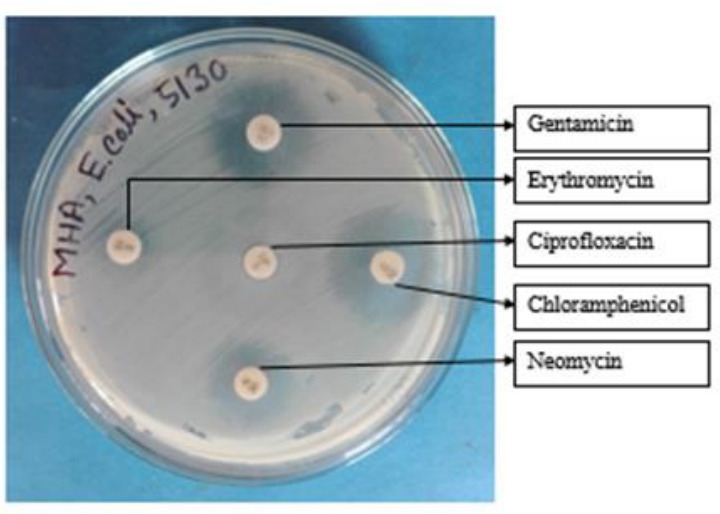

Figure 2 Antibiogram for E. coli (b)

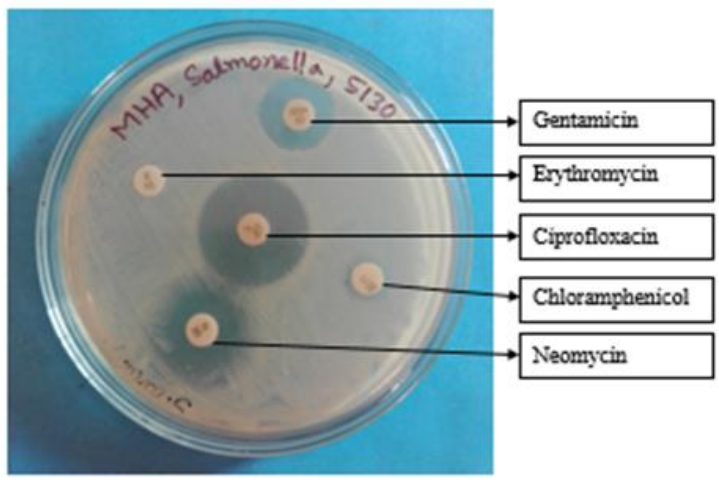

Figure 4 Antibiogram study of Salmonella spp. (b)

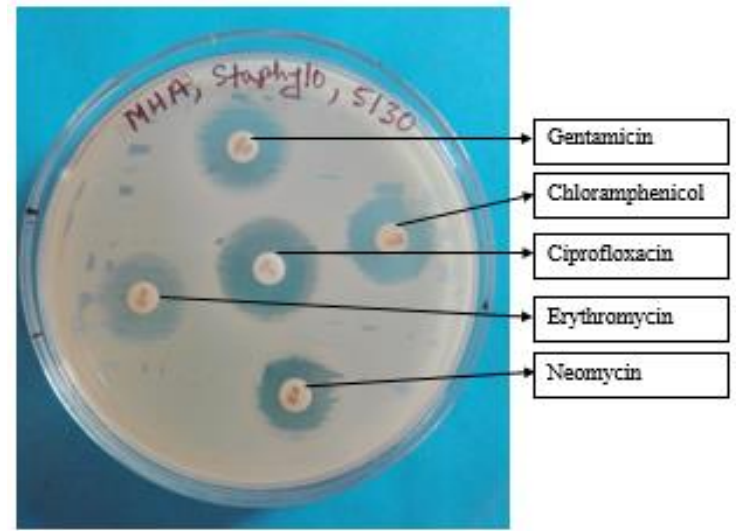

Figure 6 Antibiogram study of Staphylococcus spp. (b) 


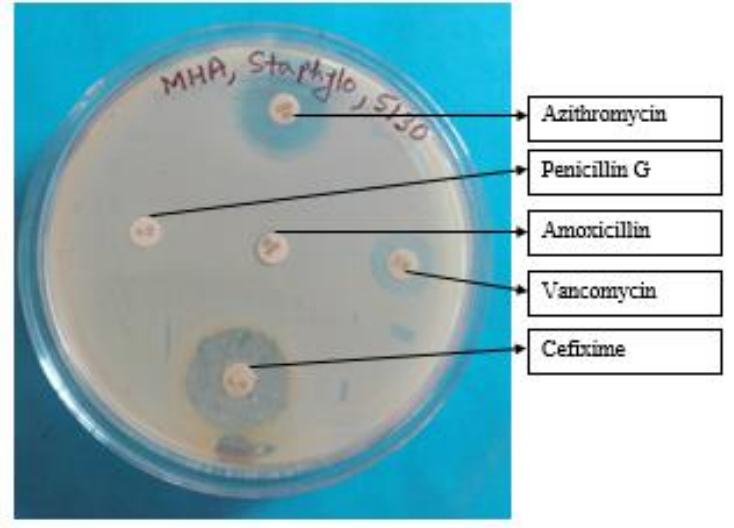

Figure 7 Antibiogram study of Pseudomonas spp. (a)

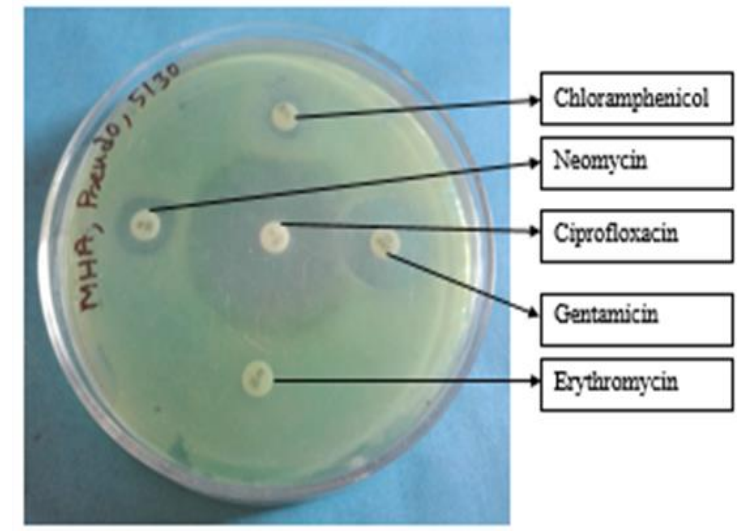

Figure 8. Antibiogram study of Pseudomonas spp. (b)

\section{Discussion}

The bacteria isolated from fishes included Escherichia coli, Staphylococcus spp., Salmonella spp., Enterobacter cloacae, Klebsiella spp., Proteus spp. and Pseudomonas spp. Fish ponds could be a source of many bacteria that isolated from Tilapia fishes in this study. In this work the bacterial isolates were obtained from gills, skin and intestines. All samples showed bacterial growth and gave 77 isolates. Out of 77 isolates $31(40.26 \%)$ were found positive for Escherichia coli, 10(12.99\%) Salmonella spp., 23 (29.87\%) Staphylococcus spp., and 13 (16.88\%) Pseudomonas spp.

Pseudomonas spp. was isolated from gills, skin and intestines of apparently healthy Oreochromis niloticus fishes this finding is identical with previous investigation in Sudan which reported the presence of Pseudomonas spp. in gills and intestines of Oreochromis niloticus fishes (Hnadi, 2008). This result is also in agreement with several authors' studies (Ryser et al., 1984; Wakabayashi et al., 1996; Mohammed, 1999; Tripathy et al., 2007; Chen and Kou, 1987), they reported the presence of Pseudomonas aeruginosa from different parts of a number of freshwater fish species. Pseudomonas aeruginosa was detected on the surface and muscle lesions of several afflicted fish species (Kar et al., 1990; Mohammed, 1999). In man P. aeruginosa causes between 10-20\% of infection in most hospitals. Pseudomonas infection is especially prevalent among patient with burn wounds, cystic fibrosis and acute leukemia. The most serious infection cause by Pseudomonas includes malignant external otitis, endopthalmitis, endocarditis, meningitis, pneumonia and septiceamia (Gerald et al., 1983).

Escherichia coli was isolated from gills and intestines of apparently healthy Oreochromis niloticus fishes in the present investigation this is in agreement with previous study in Sudan by Hnadi (2008) who reported the presence of Escherichia coli in gills and intestines of Oreochromis niloticus fish. Escherichia coli was also isolated from intestines, gills, liver, spleen and brain of different freshwater fish species (Austin and Al-Zahrani, 1988; AlHarbi, 2003; Guzman et al., 2004; Khan, 1987; Kasing et al., 1999; Nieto et al., 1984; Mohammed et al., 1999; Yilmaz et al., 2018). Most E. coli strains are important human pathogens, but some, such as serotype O157:H7 can cause serious food poisoning (Vogt and Dippold, 2005).

Salmonella spp. was isolated from gills and intestines of Oreochromis niloticus fishes also Salmonella spp., were present in all parts of the fishes (Cahill, 1990). The prevalence of Salmonella in different body parts of fishes was studied by Mohamed et al. (1997). The presence of Salmonella spp. indicates faecal contamination of water from which the fishes were collected. The freshwater lake, farmed and market fishes were $31 \%, 5 \%$ and 10 to $28 \%$, respectively (Mohamed, 1997). Adam et al. (1999) has demonstrated that fish and fish products are only occasionally associated with Salmonella and that filter feeding shell fish harvested from polluted water have been identified as higher risk products.

Current investigation Staphylococcus spp. was isolated from gills and intestines of Oreochromis niloticus fishes also in Sudan. Hnadi (2008) reported the presence of Staphylococcus spp. in gills and intestines of two freshwater fish species. Many authors reported the presence of Staphylococcus species in intestines and gills of different fish species (Austin and Al- Zahrani, 1988; Kasing et al., 1999; Nieto et al., 1984). There is strong possibility that, the fish may obtain this bacterium from ponds water because chicken manure was used as fertilizers in ponds.

In this investigation, fish pathogenic bacteria, Pseudomonas spp., Escherichia coli, Salmonella spp., Staphylococcus spp. were isolated from Tilapia (Oreochromis niloticus) fishes collected from the local fish market. This indicates these bacterial pathogens might cause serious infection leading to considerable economic losses in fishes when environmental condition altered in local market and fish's resistance was reduced.

\section{Public Health Importance}

Pseudomonas spp., Escherichia coli, salmonella spp., Staphylococcus spp. were isolated from Tilapia (Oreochromis niloticus) fishes, this indicates these fishes could be a source of infection and the possibility of transmission of these pathogens to workers in fish industry and consumers. Generally human contract fish-borne bacterial disease through ingestion of contaminated fish tissue. In Escherichia coli infection organisms invade through punctured wounds or abrasion. Although the transmission of others bacterial species has not been documented, the potential for human infection does exist 
among individual who handle diseased fish (Stoskopf, 1993).

The isolates were sensitive to gentamycin, azithromycin chloramphenicol and ciprofloxacin and resistance to amoxicillin, penicillin $\mathrm{G}$. vancomycin and erythromycin. Findings are identical with Karki et al., (2013), they also reported all isolated from fish revealed resistance to penicillin and sensitive to gentamicin. The bacterial isolates were sensitive to ciprofloxacin, which is gentamycin and this is in line with the findings of (Jawahar, 2011) whose findings were similar with bacterial human pathogens highly sensitive to ciprofloxacin, gentamycin and chloramphenicol.

The antibacterial resistance observed in the isolated Pseudomonas spp., Escherichia coli, salmonella spp., Staphylococcus spp. Might be due to indiscriminate use of those antibacterial agents in fishes where they cultured or rapid chromosomal mutation and the specific plasmid DNA. This will provide guideline to the farmers to select appropriate antibiotics to reduce the economic losses through selecting the sensitive antibiotics.

The result of isolation, identification, biochemical test and antibiotic sensitivity of the bacteria isolated from Tilapia fish in the present study indicates that the microbial contamination play an important role for the development of diseases in Tilapia fish and Some of these pathogens have tendency to transmit to man who eat fish meat or deal with fish and fish products.

\section{Conclusion}

Isolates are also common human bacterial pathogens. The fish act as a reservoir of human pathogens and the presence of highly pathogenic agents such as Salmonella species cause health hazard. Opportunistic pathogens are a potential health risk/hazard to human beings and may cause diseases to susceptible individuals especially the immunecompromised consumers potentially pathogenic to humans, in the fish suggest that if they are improperly handled, undercooked or consumed raw may contribute to the spread of the pathogens in the community. The study of antibiogram revealed that the most of the pathogens were found to be resistant to commonly used antibiotics. Most of the isolates were resistance against Amoxicillin, Penicillin G, Vancomycin and Erythromycin. A serious health hazards because of ineffective treatment of the sufferers by the commonly prescribed antibiotics. Conclusively, this research has brought to light those bacterial species associated with fresh Tilapia fish and has shown that they are potentially pathogenic to humans.

\section{Significance Statements}

This research has great impact to create public awareness about antimicrobial resistance and transmission of disease from fish to human. Furthermore, current study influence fish handler not to handle disease fish without any precaution and haphazardly. Eventually, this study will provide guideline to the farmers to select appropriate antibiotics to reduce the economic losses through selecting the sensitive antibiotics.

\section{Acknowledgements}

The authors would like to thank Department of Microbiology, Hajee Mohammad Danesh Science and Technology University and Ministry of Science and Technology for funding this research.

\section{References}

Abou El-Atta ME. 2003. Efficiency of polymerase chain Reaction (P.C.R.) in diagnosis of some bacterial fish pathogens. Ph.D. Thesis in Vet. Sci (Bacteriology, immunology and mycology), pp. 44-63.

Adam AJ, Tobaias WJ. 1999. Red Mang rove proproot habitat as a finfish nursery area; a case study of salt rivea bay, st. Croix, USVI. Proc Gulf Caribb fish inst, 46: 22-46.

Al-Harbi AH, Uddin N. 2003. Quantitative and qualitative studies on bacterial flora of hybrid tilapia (Oreochromis niloticus and $O$. aureus) cultured in earthen ponds in Saudi Arabia. Aquaculture Research, 34: 43 - 48.

Allen DA, Austin B, Colwell RR. 1983. Numerical taxonomy of bacterial isolates associated with of freshwater fishery. Journal of general microbiology, 129: 2043-2062.

Aly SEM. 1994. Pathological studies on some fish in Suez Canal area. Ph.D. Thesis (pathology) Fact. of Vet. Med. Suez. Canal University.

Angka SL, Lioe KG. 1982. Control of bacterial hemorrhagic septicaemia in cultured fish. Bul. Perel Inst. Pertan Bogor, 3(3): 13-14.

Austin B, Al-Zahrani AMJ. 1988. The effect of antimicrobial compounds on the gastrointestinal microflora of rainbow trout. Journal Fish Biology, 33: 1-14.

Belton B, Karim M, Thilsted S, Murshed-E-Jahan K, Collis W, Phillips M. 2011. Studies and Reviews 2011-53. The World Fish Center. Penang, Malaysia. p. 71.

Cabello FC. 2006. Heavy use of prophylactic antibiotics in aquaculture: a growing problem for human health and for the environment. Environmental Microbiology, 8 (7): 11371144.

Cahill MM. 1990. Bacterial flora of fishes: a review. Microbiology Ecology, 19(1): 21-41.

Cappuccino JG, Sherman N. 1996. Microbiology- A Laboratory Manual. 4th edn. California: The Benjamin/Cummings Publishing Co., Inc.

Carter GR. 1979. Diagnostic Procedures in Veterinary Bacteriology and Mycoplasma. 3rd edn. Charles C, Thomas Publicher U.S.A., pp. 398-417.

Chen HY, Kou GH. 1987. Studies on bacterial drug resistance in aquaculture I Drug resistance of bacteria in pond reared eels (Anguilla japonica). The Memoir of Bacteriology and Immunology in Fish Disease, 10: 12-24.

Chonoko U, Sule E, Ado A. 2014. Antibiotic susceptibility of pyogenic streptococci in catfish and tilapia from fresh water demonstration fish ponds, mando, kaduna. Continental J. Pharmaceutical Sciences, Wilolud Journals, 8(1): 7-15.

Douglas D. 2007. Identifying fresh water Aquarium fish disease.

Eissa IAM, Badran AF, Diab AS, Abdel-Rahman AM. 1996. "Some studies on prevailing bacterial diseases among cultured tilapias in Abbassa fish farms". Proceedings of the 3rd Vet. Med. Congress, Zagazig University, Egypt, pp. 185202.

Emikpe BO, Adebisi T, Adedeji OB. 2011. Bacteria load on the skin and stomach of Clarias Gariepinus and Oreochromis Niloticus from Ibadan, South West Nigeria: Public health implications. Journal of Microbiology and Biotechnology Research, 1: 52-59.

EUCAST. 2015. Breakpoint tables for interpretation of MICs \& zone diameters, version 5.0. 
FAO. 2007. Food and Agriculture Organization of WHO. The state of the world Fisheries and Aquaculture.

FRSS. 2012. A Comprehensive Study on High Value Fish (Tilapia, Pangas and Koi) in Bangladesh.

Gerald PB, Ricardo BV, Fainstein LJ. 1983. Infections caused by Pseudomonas aeruginosa. Reviews of Infectious Diseases, 5 (2): 279-313.

Goncalves JR, Braum G, Fernandes A, Biscaia I, Bastardo J. 1992. Aeromonas hydrophila fulminate pneumonia in a fit young man Tborax, 47: 482-483.

Guzman MC, Bistoni MA, Tamagnini LM, Gonzalez RD. 2004. Recovery of Escherichia coli in fresh water fish, Jenynsia multidentata and Bryconamericus iheringi. Water Research, 38: $2368-2374$.

Hnadi GBB. 2008. Microbial contaminations of some fresh water fish species (Oreochromis niloticus, Clarias spp and Synodontis spp). B.Sc. (Hon) Department of fisheries, University of Juba.

Jawahar AT. 2011. Food safety hazards related to emerging antibiotic resistant bacteria in cultured Freshwater fishes of Kolkata, India. Advance Journal of Food Science and Technology, 3 (1): 69-72.

Kaneko S. 1971. Microbiological study of fresh fish. New Food Industry, 13: 76-80.

Kar D, Michael RG, Kar S, Changkija S. 1990. Studies on fish epidemics from Assam. Journal of Indian Fish Association, 20: 73-75.

Karki H, Mustafa A, Master AL, Dhawale S. 2013. Antibiotic Resistant Bacteria in the Gut of Hatchery-reared Tilapia and Coho Salmon. Universal Journal of Microbiology Research, 1(3): 43-46.

Kasing A, Asiah MY, Kumbang J. 1999. Distribution of bacteria in tropical freshwater fish and ponds. International Journal of Environmental Health Research, 9 (4): 285-292.

Khan SM, Nunjurul H, Shafi M. 1987. Study of the bacteriological flora in the alimentary canal of Clarias batrachus and Heteropneustes fossilis in Bangladesh. Bangladesh Association for the Advancement of Science, Dhaka (Bangladesh). Proceedings of the $12^{\text {th }}$ Annual Bangladesh Science Conference, pp. 35-36.

Ladipo O, Fabiyi and Fatula GT. 1981. Marketing and distribution of fish in Nigeria. Report submitted to the federal development of fisheries, Lagos. p. 35.

Leisner JJ, Vancanneyt M, Rusul G, Pot B, Lefebvre K, Fresi A, Tee LT. 2001. Identification of lactic acid bacteria constituting the predom, nating microflora in an acid feamented condiment (tempoyak) popular in Malaysia. International Journal of food microbiology, 63: 147-157.
Mhango M, Mpuchane SF, Gashe BA. 2010. Incidence of indicator organisms, opportunistic and pathogenic bacteria in fish. African Journal of Food, Agriculture, Nutrition and Development, 10(6): 4202-4218.

Mohamed HA, Lakshmanaperumalsamy P. 1997. Prevalence of Salmonella in fish and crustaceans from markets in Coimbatore, South India. Food Micro., 14(2): 111-116.

Mohammed XSA. 1999. Quality monitoring of some farm in Kafr Elsheikh. Association of Medical Journal, 41: 152- 161.

Roberts RJ, Horne MT. 1978. Bacterial meningitis in farmed rainbow trout salmogarirdneri Richrdson, affected with chronic pancreatic necrosis. Journal of fish diseases, 1: 157164.

Romana-Eguia MRR, Ikeda M, Basiao ZU, Taniguchi N. 2004. Genetic diversity in farmed Asian Nile and red hybrid tilapia stocks evaluated from microsatellite and mitochondrial DNA analysis. Aquaculture, 236:131-150.

Ryser ET, Marth EH, Taylor SL. 1984. Histamine production by psychrotrophic pseudomonads isolated from fish. Journal of Food Protection, 47: 378-380.

Shirak A, Cohen-Zinder M, Barroso RM, Seroussi E, Ron M, Hulata G. 2009. DNA bar-coding of Israeli indigenous and introduced cichlids. Israeli Journal of Aquaculture, 61: 83-88.

Stoskopf MK. 1993. Zoonotic diseases. In: Fish medicine. W. B. Saunders Company. pp. 214- 217.

Tripathy S, Kumar N, Mohanty S, Samanta M, Mandal RN, Maiti NK. 2007. Characterization of Pseudomonas aeruginosa isolated from freshwater culture systems. Microbiological Research, 162 (4): 391-396

Vogt RL, Dippold L. 2005. Escherichia coli O157:H7 outbreak associated with consumption of ground beef. Public Health Reports, 2: 174-178.

Wakabayashi H, Egusa S. 1972. Characteristics of Pseudomonas spp. from an epizootic of pond-cultured eels. Bull. Japan Soc. Scient. Fish, 38: 577-587.

Weinstein MR, Litt M, Kertesz DA, Wyper P, Rose D, Coulter M, McGeer A, Facklam R, Ostach C, Willey BM, Borczyk A, Low DE. 1997. Invasive infections due to a fish pathogen, Streptococcus iniae. England Journal of Medicine, 337: 589594.

WHO. 2007. Food safety issues associated with products from aquaculture. T.R.S. No. 883, World Health Organization, Geneva, Switzerland.

Zlotkin A, Chilmonczyk S, Eyngor M, Ghittino C, Hurvitz A. 2003. Trojan horse effect: phagocyte-mediated Streptococcus iniae infection of fish. Infect Immun, 71 (5): 2318-2325. 